\title{
移植片対宿主病と移植片対腫瘍効果における細胞外アデノシン産生系の機能解析と その薬学的制御に関する研究
}

\author{
塚本 宏 樹
}

\section{Extracellular Adenosine Is a Therapeutic Target for Limiting Graft-versus-Host Disease and Enhancing the Graft-versus-Tumor Effect against Hematopoietic Malignancy}

\author{
Hiroki Tsukamoto \\ Laboratory of Oncology, Pharmacy Practice and Sciences, Graduate School of Pharmaceutical Sciences, \\ Tohoku University; 6-3 Aoba, Aramaki, Aoba-ku, Sendai 980-8578, Japan.
}

(Received June 22, 2014)

\begin{abstract}
Allogeneic hematopoietic stem cell transplantation is performed in patients with hematologic malignancies refractory to chemotherapy. However, its efficacy is often limited by the development of graft-versus-host disease (GVHD) secondary to the allogeneic interaction of donor T cells with host dendritic cells. On the other hand, the antihost cytotoxicity of donor T cells enhances the graft-versus-tumor (GVT) effect. Extracellular adenosine generated by CD73/ecto5 '-nucleotidase from ATP via AMP plays pleiotropic roles under physiological and pathological conditions by engaging four adenosine receptors. One study recently demonstrated that ATP released from damaged cells exacerbates GVHD by activating the $\mathrm{P} 2 \mathrm{X}_{7}$ receptor on host dendritic cells. In this review, we summarize our recent findings on the immunosuppressive role of extracellular adenosine in GVHD and the GVT effect. We have shown that in MHC-mismatched bone marrow transplantation, CD73 deficiency, particularly in the recipient, enhanced GVHD severity because of excessive donor T-cell expansion. Severe GVHD was enhanced by repeated administration of a CD73 inhibitor or an adenosine receptor antagonist. A competitive engraftment assay identified endogenous $\mathrm{A}_{2 \mathrm{~A}} \mathrm{AR}$ signaling in donor $\mathrm{T}$ cells as part of a regulatory mechanism by CD73-generated adenosine. Pharmacological inhibition of CD73 enhanced the GVT effect against B-cell lymphoma and improved survival in tumor-relapsing mice after transplantation. Along with our findings, we herein introduce a novel concept that CD73-generated adenosine counteracts the ATP-evoked allogeneic immune reaction as a negative regulatory mechanism in GVHD. Pharmacological manipulation of CD73 activity could be a therapeutic strategy to limit GVHD and to preserve the GVT effect against hematopoietic malignancy.
\end{abstract}

Key words_ CD73; adenosine; graft-versus-host disease; graft-versus-tumor effect; ecto-5'-nucleotidase; adenosine receptor

\section{1.はじめに}

造血幹細胞移植は，骨髄破壊的な前処置後に造血 幹細胞を移植し，血球系を再構成させる移植医療で あり, 再生不良性貧血や免疫不全症などの先天性造 血器疾患や造血器腫瘍が適応である. 1,2) 造血幹細胞 の源である骨髄や臍帯血の公的細胞バンクも設立さ れ，免疫抑制剤の開発や移植前処置の改良とも相ま つて, 造血幹細胞移植の適応は拡大している. 特

The author declares no conflict of interest.

東北大学大学院薬学研究科がん化学療法薬学分野 （干980-8578 仙台市青葉区荒巻字青葉 6-3)

e-mail: tsukamoh@m.tohoku.ac.jp

本総説は，平成 25 年度日本薬学会東北支部奨励賞の受 賞を記念して記述したものである.
に，化学療法や放射線療法に抵抗性の難治性造血器 腫瘍では, 残された数少ない有効な治療法の 1 つと して期待されている。悪性造血器腫瘍の化学療法で は，通常，その副作用のために治療の強度を十分に 高めることができないため, 不十分な治療効果や, いつたん寛解したかのようにみえる患者でも，残存 腫瘍による再発が問題になる。一方，造血幹細胞移 植では，ドナ一の造血幹細胞で造血系を再構築させ ることが可能であるため, より高い強度の化学療法 や骨髄破壊的な放射線照射によって高い治療効果を 得ることができる。しかしながら，このような造血 幹細胞移植の治療効果は, 移植片対宿主病 (graftversus-host disease; GVHD) によつて大きく制限さ れる症例が依然多く, 現代の移植医療における大き 
な問題となつている. ${ }^{1,2)}$

GVHD は，移植片が非自己である患者を攻撃す る免疫病で, ドナー $\mathrm{T}$ 細胞が宿主やドナーの抗原 提示細胞によって活性化され発症する. ${ }^{1,2)}$ HLA 八 プロタイプの不一致が GVHD 発症の最も大きなリ スクファクターであるが，SNP 等に起因する minor histocompatibility antigen の存在によっても GVHD は発症する。 GVHD はいつたん発症すると その症状は劇的であるため, 予後は極めて悪く, GVHD の発症予防が極めて重要になる，GVHDを 予防するためには，抗胸腺ブロブリン等によるド ナー移植片中の $\mathrm{T}$ 細胞の除去やシクロスポリン等 の免疫抑制剂の投与を必要とするが，その代償とし てドナーの造血幹細胞が宿主に残存する免疫系によ つて排除される定着不全や非特異的免疫抑制による 日和見感染のリスクが増加する。悪性造血器腫瘍の 治療では，ドナーのアロ反応性 $\mathrm{T}$ 細胞による移植 片対腫瘍効果（graft-versus-tumor effect; GVT）も 覀性腫瘍の根治に奏功するため, 非特異的な免疫抑 制は移植後の残存腫瘍による再発リスクも上昇させ る.このように，悪性造血器腫瘍における同種造血 幹細胞移植は, GVHD を抑制し, 最大限の GVT を達成する薬学的管理が必要不可欠であり， GVHD の発症機序やその病態の解明は重要な研究 課題である。本総説では，GVHDの発症における 内因性アデノシンの機能，そしてアデノシン産生系 の薬学的制御による造血器腫瘍の新規治療法の可能 性についてわれわれの成果を中心に概説する.

\section{2. 細胞外アデニンヌクレオチド代謝系}

アデノシンは，DNA・RNA の構成成分やエネル ギー通貨である ATP の前駆体として重要である が，これら細胞内中間代謝体としての役割に加え， 細胞間情報伝達を担う細胞外シグナル伝達分子とし ても機能する (Fig. 1). 3,4) 細胞外で産生したアデノ シンは, 細胞膜上に発現するアデノシン受容体に結 合し，アゴニストとして作用する。 G タンパク質 共役型受容体であるアデノシン受容体は，4つのサ ブタイプ（ $\left.\mathrm{A}_{1}, \mathrm{~A}_{2 \mathrm{~A}}, \mathrm{~A}_{2 \mathrm{~B}}, \mathrm{~A}_{3} \mathrm{AR}\right)$ が同定され，いず れも比較的広範の細胞, 組織に発現が認められる. アデノシン受容体欠損マウスによる解析では，各欠 損マウス特有の表現型が観察され, 循環器系や神経 系，免疫系を始めとし，多彩な役割を果たすことが 示されている.アデノシン受容体を標的とした選択

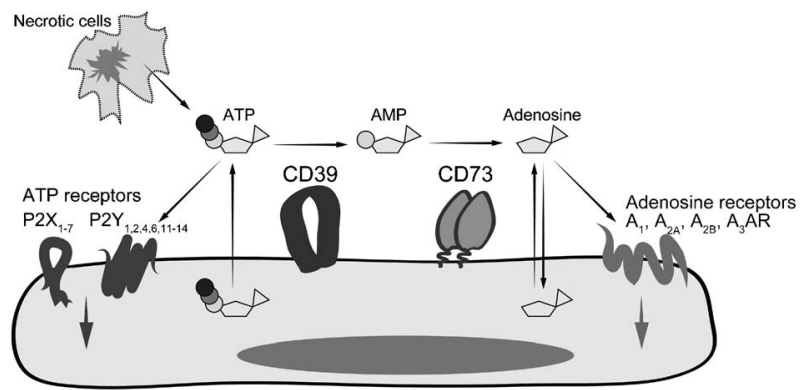

Fig. 1. Schema of Generation and Action of Extracellular Adenosine

ATP, released from dying or damaged cells, is metabolized to AMP by CD39 and then to adenosine by CD73 on the cell surface. Extracellular adenosine engages four adenosine receptors, whereas ATP acts on P2X and P2Y receptors.

的アゴニストやアンタゴニスト開発も積極的に行わ れ，様々な疾患に対する新規治療薬として期待され ている.

細胞外アデノシンは，主に2つの経路によつて産 生される. ${ }^{3,4)}$ 第一は, 細胞内で産生されたアデノシ ンのヌクレオシドトランスポーターによる細胞外輸 送である。第二には，細胞外に遊離された ATP や $\mathrm{ADP}$ 等のアデニンヌクレオチドからの代謝反応に より供給される.ATPからアデノシンへの分解は 2 段階の酵素反応により行われる。ATP は ectonucleoside triphosphate diphosphohydrolase 1 (ENTPD1，CD39）によりAMPへと分解され, ecto-5'-nucleotidase (E5NT, CD73) によりアデノシ ンへと分解される。基質である ATP は恒常的な細 胞外分泌に加え, 細胞障害等によっても一過性に放 出される。ATPが結合する受容体も, チャネル型 受容体 $\mathrm{P} 2 \mathrm{X}_{1-7}$ や $\mathrm{G}$ タンパク質共役型受容体である $\mathrm{P} 2 \mathrm{Y}_{1,2,4,6,11-14}$ 等が複数同定され, 細胞外 ATP/ $\mathrm{AMP} /$ アデノシン産生系が生体の恒常性維持に貢献

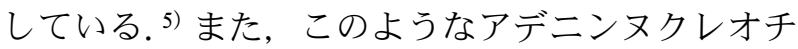
ド代謝系は，虚血再灌流障害，悪性腫瘍，神経性疼 痛等の様々な疾患の発症や病態に関係していること

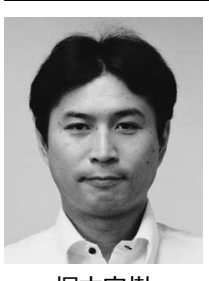

東北大学大学院薬学研究科 助教. 1999 年東北大学薬学部卒業. 2004 年東 北大学大学院薬学研究科 博士 (薬学) 取 得. 2004 年順天堂大学環境医学研究所 研究員. 2005 年佐賀大学医学部助教. 2008 年シンシナティ大学研究員. 2009 年オクラホマ医学研究財団研究員. 2011 年佐賀大学医学部助教. 2013 年よ り現職. 

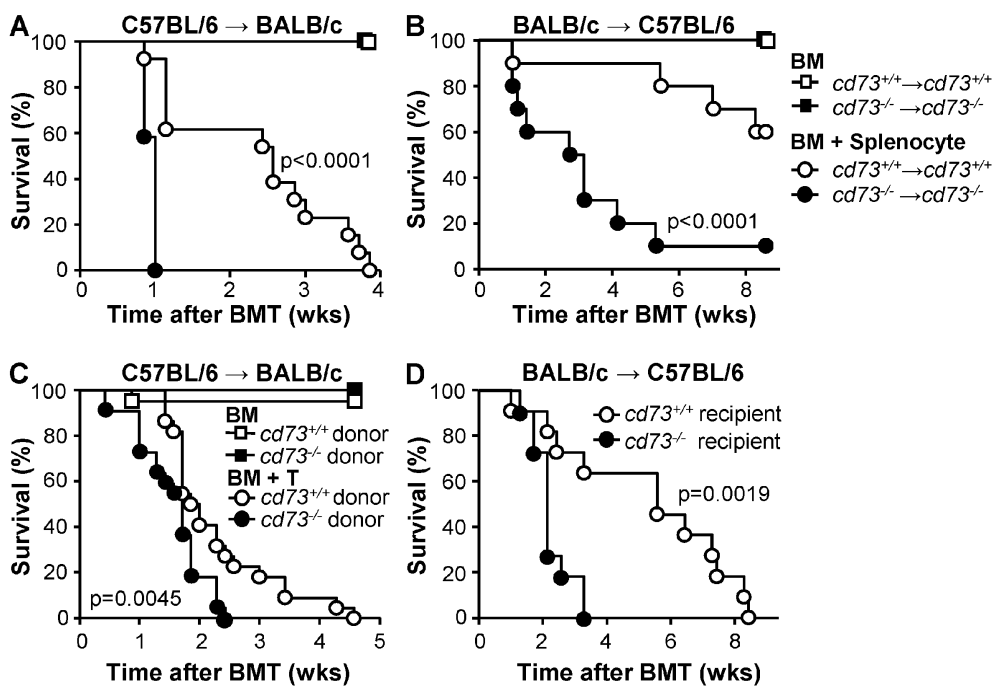

Fig. 2. CD73 Deficiency Enhances GVHD Mortality

All bone marrow (BM) transplantations (BMTs) were performed on lethally irradiated mice, and survival was monitored for the indicated times. (A) $c d 73^{+/+}$ and $c d 73^{-/-} \mathrm{BALB} / \mathrm{c}$ mice were transplanted with $5 \times 10^{6} \mathrm{BM}$ cells $\pm 10 \times 10^{6}$ splenocytes from $c d 73^{+/+}$or $c d 73^{-/-}$C57BL/6 mice, respectively $(n=12$ to $13, p<$ 0.0001). (B) $c d 73^{+/+}$and $c d 73^{-/-}$C57BL $/ 6$ mice were transplanted with $5 \times 10^{6} \mathrm{BM}$ cells $\pm 15 \times 10^{6}$ splenocytes from $c d 73^{+/+}$or $c d 73^{-/-} \mathrm{BALB} / \mathrm{c}$ mice, respectively $(n=10, p<0.0001)$. (C) $c d 73^{+/+} \mathrm{BALB} / \mathrm{c}$ mice were transplanted with $5 \times 10^{6} \mathrm{BM}$ cells $\pm 3 \times 10^{5} \mathrm{CD} 4^{+} / \mathrm{CD} 8^{+}$splenic $\mathrm{T}$ cells from $c d 73^{+/+}$or $c d 73^{-/-}$ C57BL $/ 6$ mice $(n=22, p=0.0045)$. (D) $c d 73^{+/+}$and $c d 73^{-/-}$C57BL/ 6 mice were transplanted with $5 \times 10^{6} \mathrm{BM}$ cells and $2 \times 10^{5} \mathrm{CD} 4^{+} / \mathrm{CD} 8^{+}$splenic T cells from a $c d 73^{+/+} \mathrm{BALB} / \mathrm{c}$ donor $(n=11, p=0.0019){ }^{16)}$

が明らかとなってきている.

\section{CD73 の発現と機能}

われわれは，これまで AMP をアデノシンに分解 する膜型 ecto-5'-nucleotidase である CD73 に着目 して研究をしてきた．CD73 は，T 細胞や血管内皮 細胞，上皮細胞の細胞膜上に GPI アンカーを介し て発現し, 細胞外アデノシンの産生を制御してい る. ${ }^{6)}$ また，他の GPI アンカー型タンパク質によく 認められるように，一部はアンカー構造を欠く分泌 型として血液中等の細胞外液へと分泌される. CD73 欠損マウスでは, 多くの臓器において細胞外 アデノシンの産生量が低下し，主要な細胞外アデノ シンン産生酵素であることが明らかとなってい る. ${ }^{7)}$ また, CD73 欠損マウスでは, 白血球の血管 外遊走や血管透過性の克進といつた表現型が認めら れ, ${ }^{7-11)}$ これらの一部はアデノシン受容体欠損マウ スの表現型とも一致する. ${ }^{7,10-12)}$ また，近年では， 制御性 $\mathrm{T}$ 細胞や間葉系幹細胞等が CD73 を発現す ることも報告されており，これら細胞による免疫抑 制機構に CD73 産生性細胞外アデノシンが関与する ことも明らかにされつつある. ${ }^{13,14)}$

\section{CD73 による GVHD の発症抑制}

近年, ATP が細胞障害に起因して分泌される

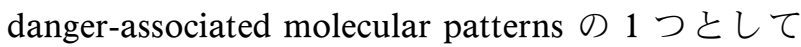

GVHD を増悪化することが報告された. ${ }^{15)}$ 移植前 処置である放射線化学療法に伴い放出された ATP が宿主の樹状細胞に発現する $\mathrm{P}^{2} \mathrm{X}_{7}$ 受容体に結合 し, 樹状細胞からのサイトカイン産生やCD80/ CD86 等の副刺激分子の発現を六進する。 その結 果，ドナーのアロ反応性 $\mathrm{T}$ 細胞は活発に増殖して IFN- $\gamma$ の産生を六進し, 急性 GVHD を増悪化す る。いったん発症した GVHD は組織障害による ATP の産生を増長し，GVHD の病態はより一層重 症化する，そこで，われわれは，ATP 代謝物であ るアデノシンが GVHD 増悪化に拮抗する生理的抑 制機構を担うと仮説し，GVHD における細胞外ア デノシン産生酵素 CD73 の役割についてマウス MHC 不適合骨䯣移植モデルにより検討した. ${ }^{16)}$ 放 射線照射した CD73 欠損 BALB/c マウスに同欠損 C57BL / 6 マウスの $\mathrm{T}$ 細胞と骨髄細胞を移植し GVHD の重症度を検討したところ，CD73 野生型 マウス間の骨䯣移植に比へ，著しい体重減少が観察 され，生存率も有意に低下した [Fig. 2(A)]。同様 に, $\mathrm{C} 57 \mathrm{BL} / 6$ ドナー $\mathrm{T}$ 細胞の $\mathrm{BALB} / \mathrm{c}$ マウスへの 移植でも GVHD は重症化した [Fig. 2(B)]。また, GVHD 発症におけるドナーとレシピエントの CD73 の役割について検討したところ，レシピエン トの CD73 が欠損した場合に重度の GVHD が再現 
され [Figs. 2(C) and (D)]，主にレシピエント由 来の CD73 が GVHD の発症を抑制することが明ら かとなつた。ささらに, GVHD 重症化の臟器特異性 についても病理学的に解析したところ，GVHD 標 的臓器である肝臓, 小腸，大腸いずれの臓器におい ても高い病理組織学的スコアが観察され, 組織非特 異的に GVHD が重症化していることが明らかとな つた. ${ }^{16)}$

\section{CD73 損による GVHD 重症化のメカニズ} 厶

GVHD は，ドナー移植片中の $\mathrm{T}$ 細胞がレシピエ ントを非自己と認識して攻撃することで発症す る. ${ }^{1,2)} \mathrm{CD} 73$ 欠損による GVHD 重症化の原因を追 究するため, luciferase 遺伝子を導入した FVB/N トランスジェニックマウス由来の $\mathrm{T}$ 細胞を C57BL/ 6 マウスに移植し, bioluminscence imaging により ドナー $\mathrm{T}$ 細胞の増殖を in vivo 解析した。その結 果，野生型レシピエントに比べ，CD73 欠損レシピ エントでは, ドナー $\mathrm{T}$ 細胞が著しく増加すること が明らかになった [Figs. 3(A) and (B)]。さらに, CFSE 標識による細胞分裂のフローサイトメトリー 解析から，この増加はドナー $\mathrm{T}$ 細胞の活発な増殖 に起因することが判明し [Fig. 3(C)]，CD73 欠損 レシピエントでは高い IFN- $\gamma$ の産生も確認され た. ${ }^{16)}$ 放射線照射によりレシピエント内の樹状細胞 は活性化し，アロ反応性ドナー $\mathrm{T}$ 細胞の活性化を 惹起する. ${ }^{15)}$ そこで，CD73 欠損による樹状細胞の 活性化についても検討を加えた。マウスを放射線照 射した後，脾臓中の樹状細胞における CD86 の発現 レベルの上昇を検討したところ，CD73 欠損による 変化は観察されなかった. ${ }^{16)}$ また, この結果と一致 して, リンパ球混合培養試験における CD73 欠損樹 状細胞のアロ反応性 $\mathrm{T}$ 細胞刺激活性に違いは認め られなかった。 ${ }^{16)}$ したがって，CD73 の欠損による $\mathrm{T}$ 細胞の過剰増殖はレシピエントの樹状細胞を介し た間接的作用ではないと考えられた。また，近年， CD73 や CD39 が制御性 $\mathrm{T}$ 細胞に発現し, 細胞外ア デノシンの産生を介して免疫抑制的な機能の一端を 担うことが明らかにされてきた. ${ }^{13,17)}$ そこで，脾臟 と標的臓器である大腸におけるドナー Foxp $^{+} \mathrm{CD} 4^{+}$ $\mathrm{CD} 25^{+}$制御性 $\mathrm{T}$ 細胞の細胞数を検討したところ,

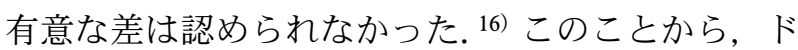
ナー T 細胞の活性化に制御性細胞の関与は低いと
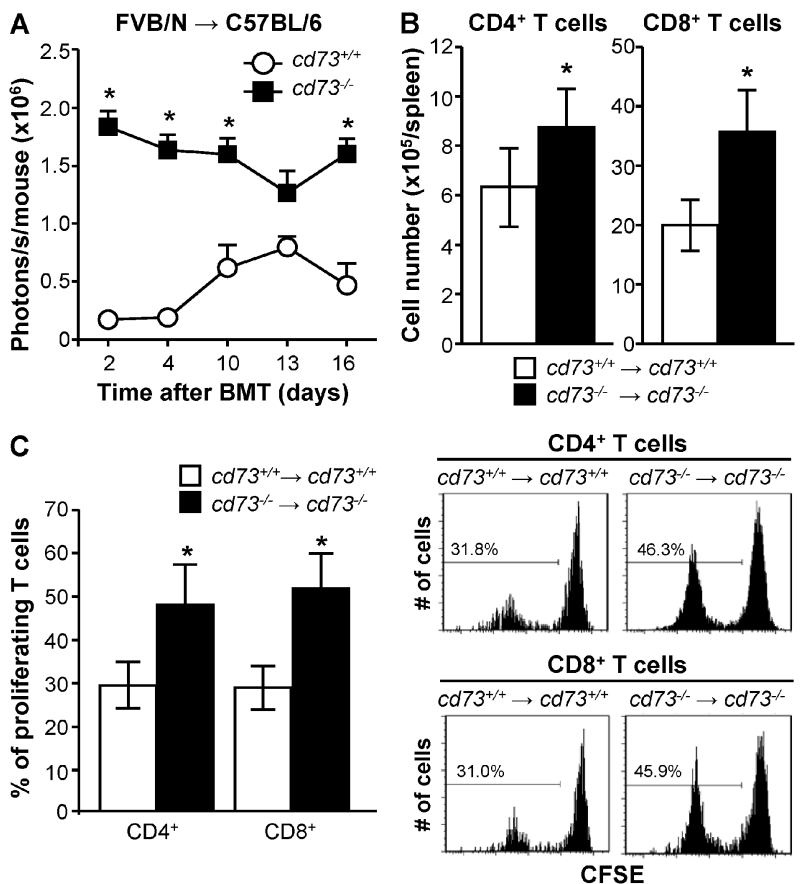

Fig. 3. CD73 Deficiency Leads to Increased Expansion of Allogeneic T Cells after BMT

(A) Irradiated $c d 73^{+/+}$and $c d 73^{-/-}$C57BL/6 mice were transplanted with $5 \times 10^{6} \mathrm{BM}$ cells and $1 \times 10^{6} \mathrm{CD}^{+} / \mathrm{CD}^{+}$splenic $\mathrm{T}$ cells from a $c d 73^{+/+}$ $l u c^{+}$-transgenic $\mathrm{FVB} / \mathrm{N}$ donor. In vivo expansion of $l u c^{+} \mathrm{T}$ cells was quantified by bioluminescence imaging (mean \pm S.E.M, ${ }^{*} p<0.05, n=3$ ). (B) $c d 73^{+/+}$or $c d 73^{-/-}$C57BL $/ 6$ mice were transplanted with $5 \times 10^{6} \mathrm{BM}$ cells and $10 \times 10^{6}$ spleen cells from $c d 73^{+/+}$or $c d 73^{-/-}$BALB/c mice, respectively. Six to seven days after BMT, the numbers of donor $\mathrm{CD} 4^{+}$and $\mathrm{CD} 8^{+} \mathrm{T}$ cells in the recipient spleens were determined by flow cytometry (mean \pm S.D., ${ }^{*} p<0.05, n=3$ to 5 ). (C) $c d 73^{+/+}$or $c d 73^{-/-}$C57BL $/ 6$ mice were transplanted with $5 \times 10^{6} \mathrm{BM}$ cells and $10 \times 10^{6} \mathrm{CFSE}$-labeled spleen cells from $c d 73^{+/+}$or $c d 73^{-/-}$BALB/c mice, respectively. Three days later, proliferating donor splenic $\mathrm{CD} 4^{+}$and $\mathrm{CD} 8^{+} \mathrm{T}$ cells were identified by loss of CFSE intensity (mean \pm S.D., ${ }^{*} p<0.05, n=3$ to 5 ). ${ }^{16}$ )

考えられた。

6. CD73 産生性細胞外アデノシンによる T 細胞 $\mathbf{A}_{2 \mathrm{~A}} \mathbf{A R}$ 受容体を介したアロ反応性 $\mathbf{T}$ 細胞の抑制

CD73 は, ecto-5'-nucleotidase として働く一方, 細胞間接着分子や $\mathrm{T}$ 細胞受容体シグナルを増強す るシグナル伝達受容体として機能することが報告さ れている。古そこで，CD73 欠損マウスにおける GVHD の重症化が細胞外アデノシンの産生に依存 しているのか, CD73 の酵素活性阻害薬 $\alpha, \beta$-methylene adenosine 5 -diphosphate (APCP) やアデノシ ン受容体拮抗薬 caffeine を用いて検討した。その結 果，いずれの薬剤を移植後に反復投与した場合にお いても, CD73 欠損同様の GVHD の重症化が認め られ [Figs. 4(A) and (B)], CD73 産生性アデノシ ンが GVHD を抑制すると考えられた。本結果を受 けて，細胞外アデノシンによる GVHD 発症抑制を 

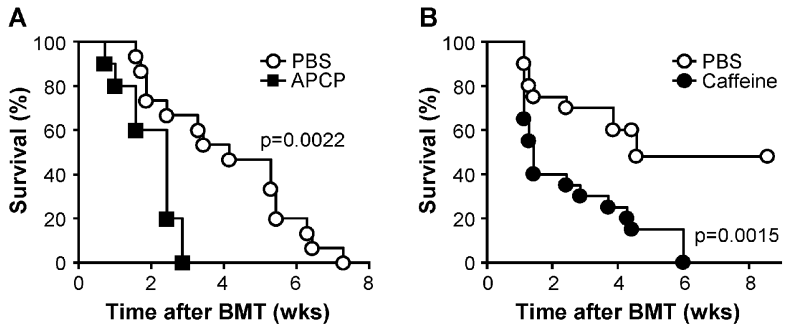

C

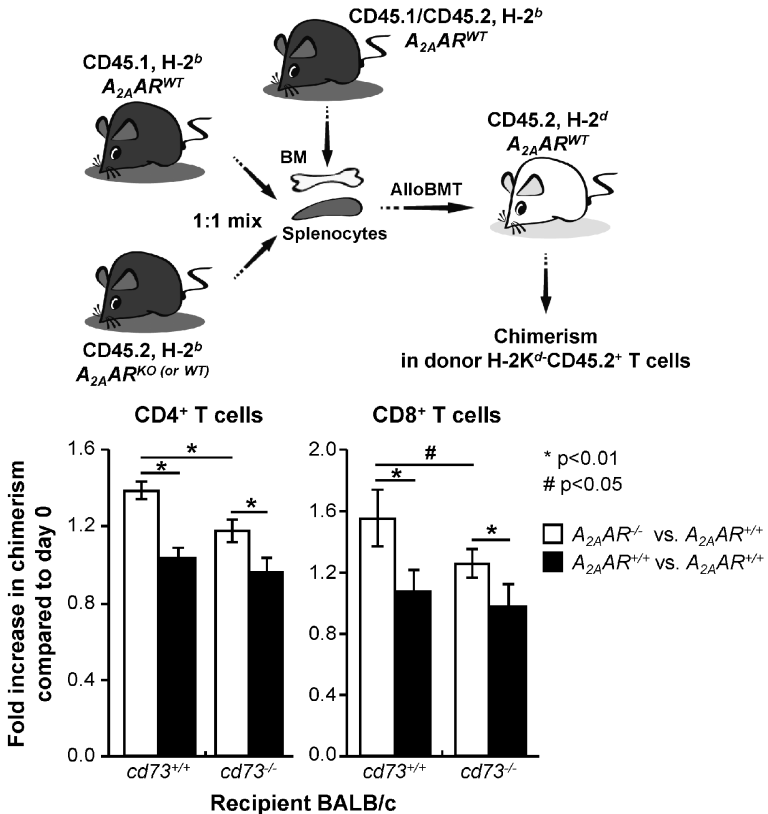

Fig. 4. Extracellular Adenosine Reduces the Severity of GVHD at Least in Part via Signaling through the $\mathrm{A}_{2 \mathrm{~A}} \mathrm{AR}$ on T Cells

(A) Irradiated C57BL $/ 6$ mice were transplanted with $5 \times 10^{6} \mathrm{BM}$ cells and $2 \times 10^{5} \mathrm{CD}^{+} / \mathrm{CD}^{+}$splenic $\mathrm{T}$ cells from $\mathrm{BALB} / \mathrm{c}$ mice and intraperitoneally administered the CD73 inhibitor APCP or PBS ( $n=10$ to 15 , $p=0.0022$ ) . (B) Irradiated C57BL $/ 6$ mice received $5 \times 10^{6} \mathrm{BM}$ cells and $20 \times$ $10^{6}$ spleen cells from BALB/c mice followed by intraperitoneal injection of caffeine $(10 \mathrm{mg} / \mathrm{kg})$ or PBS six times in the first week after BMT and three to five times in the second week and thereafter $(n=20 /$ group, $p=0.0015)$. (C) Irradiated $\mathrm{BALB} / \mathrm{c}\left(\mathrm{H}-2 \mathrm{~K}^{d}, \mathrm{CD} 45.2, A_{2 A} A R^{+/+}\right)$mice received an intravenous injection of $5.0 \times 10^{6} \mathrm{BM}$ cells from CD45.1 ${ }^{+} \mathrm{CD} 45.2^{+} \mathrm{C} 57 \mathrm{BL} / 6$ F1 congenic mice $\left(\mathrm{H}-2 \mathrm{~K}^{b}, A_{2 A} A R^{+/+}\right)$together with $2.5 \times 10^{6}$ each of splenocytes prepared from $A_{2 A} A R^{+/+} \mathrm{C} 57 \mathrm{BL} / 6$ congenic mice $\left(\mathrm{H}-2 \mathrm{~K}^{b}\right.$, $\mathrm{CD} 45.1)$ and from $A_{2 A} A R^{-1-}$ or $A_{2 A} A R^{+/+} \mathrm{C} 57 \mathrm{BL} / 6$ mice $\left(\mathrm{H}-2 \mathrm{~K}^{b}\right.$, $\mathrm{CD} 45.2)$. On day 8, spleen cells were prepared from recipient mice and analyzed by flow cytometry for the expression of CD4, CD8, H-2K $\mathrm{K}^{d}, \mathrm{CD} 45.1$, and CD45.2 to determine the degree of chimerism. The bar graph shows the changes in the percentages of $\mathrm{CD} 45.2^{+} \mathrm{CD} 45.1^{-}$cells in total donor $\mathrm{CD} 4{ }^{+}$ and $\mathrm{CD}^{+} \mathrm{T}$ cells after BMT compared with that in the preinjection donor cells (day 0): open bar, $A_{2 A} A R^{-/-} v s . A_{2 A} A R^{+/+}$; solid bar, $A_{2 A} A R^{+/+} v s$. $A_{2 A} A R^{+/+}$(mean \pm S.D., $n=5,{ }^{*} p<0.01, \# p<0.05$ ). This experiment was performed using $c d 73^{+/+}$and $c d 73^{-/-}$BALB/c mice as recipients. ${ }^{16)}$

担う責任受容体の同定を試みた。CD73 欠損マウス ではドナー T 細胞の過剰な活性化が認められるこ とから， T 細胞に発現するアデノシン受容体が細胞 外アデノシンに結合し， T 細胞の活性化を抑制する と考えた. GVHDを発症したマウスからドナーT 細胞を単離し，4つのアデノシン受容体について $m R N A$ 発現レベルを検討したところ, $\mathrm{A}_{2 \mathrm{~A}} \mathrm{AR}$ の発 現が CD4, CD8 T 細胞のいずれにおいても上昇し ていた. ${ }^{16)} \mathrm{A}_{2 \mathrm{~A}} \mathrm{AR}$ 選択的アゴニストは $\mathrm{T}$ 細胞の活 性化を抑制し，同種皮膚移植片の拒絶反応や GVHDの発症を抑制することが報告されてい る. ${ }^{18,19)}$ そこで，内因性細胞外アデノシンが $\mathrm{T}$ 細胞 に発現する $\mathrm{A}_{2 \mathrm{~A}} \mathrm{AR}$ を活性化し， $\mathrm{T}$ 細胞の活性化を 制御している可能性について， $\mathrm{A}_{2 \mathrm{~A}} \mathrm{AR}$ 欠損マウス 由来ドナー $\mathrm{T}$ 細胞と野生型ドナー $\mathrm{T}$ 細胞の competitive engraftment assay を実施した。その結果， $\mathrm{A}_{2 \mathrm{~A}} \mathrm{AR}$ 欠損ドナー $\mathrm{T}$ 細胞は野生型 $\mathrm{T}$ 細胞に比べて 増殖し易く， $\mathrm{A}_{2 \mathrm{~A}} \mathrm{AR}$ シグナルがアロ反応性 $\mathrm{T}$ 細胞 の活性化を抑制していることが明らかとなった [Fig. 4(C)]。 また，レシピエントにCD73 欠損マ ウスを用いた場合， $\mathrm{A}_{2 \mathrm{~A}} \mathrm{AR}$ 欠損ドナー $\mathrm{T}$ 細胞の増 殖が軽減されたことから，CD73 によって産生され る内因性細胞外アデノシンがドナー $\mathrm{T}$ 細胞の $\mathrm{A}_{2 \mathrm{~A}}$ AR に結合し，アロ反応性 $\mathrm{T}$ 細胞の活性化を抑制し ていると考えられた.

以上の研究から, danger signal であるATPから CD73 依存性に産生される細胞外アデノシンがド ナー $\mathrm{T}$ 細胞の $\mathrm{A}_{2 \mathrm{~A}} \mathrm{AR}$ を活性化し，アロ反応性 $\mathrm{T}$ 細 胞の活性化を抑制する GVHD の生理的防御メカニ ズムを解明した。

\section{CD73 の阻害による GVT 効果の増強と移植} 後残存腫瘍の再発予防

GVHD におけるドナー $\mathrm{T}$ 細胞による細胞障害反 応は, 宿主に由来する悪性腫瘍には抗腫瘍効果とし て奏功する. $1,2,20) こ の ~ G V T$ 効果を応用し，造血幹 細胞移植後の腫瘍再発や移植後に残存微小病変が認 められた場合などは，ドナーリンパ球による輸注療 法が適応となる. CD73 欠損マウスではドナー T 細 胞の過剰な活性化による宿主障害反応の増強が認め られたことから [Fig. 5(A)]，CD73 の阻害によっ て GVT 効果を増強し, 移植後残存腫瘍による再発 を予防できる可能性が考えられた。そこで，放射線 照射した BALB/c マウスに，C57BL/6 ドナー骨䯣 細胞を移植後, $\mathrm{BALB} / \mathrm{c}$ と同系の luciferase 導入 $\mathrm{B}$ リンパ球性白血病細胞株 A20 を移植し, 残存腫瘍 による腫瘍再発モデルを再現した。ドナーC57BL/ $6 \mathrm{~T}$ 細胞を投与後, CD73 阻害薬を 1 週間反復投与 し, in vivoにおける $\mathrm{A} 20$ 白血病細胞の増殖を bioluminescence imaging にて追跡したところ，ve- 


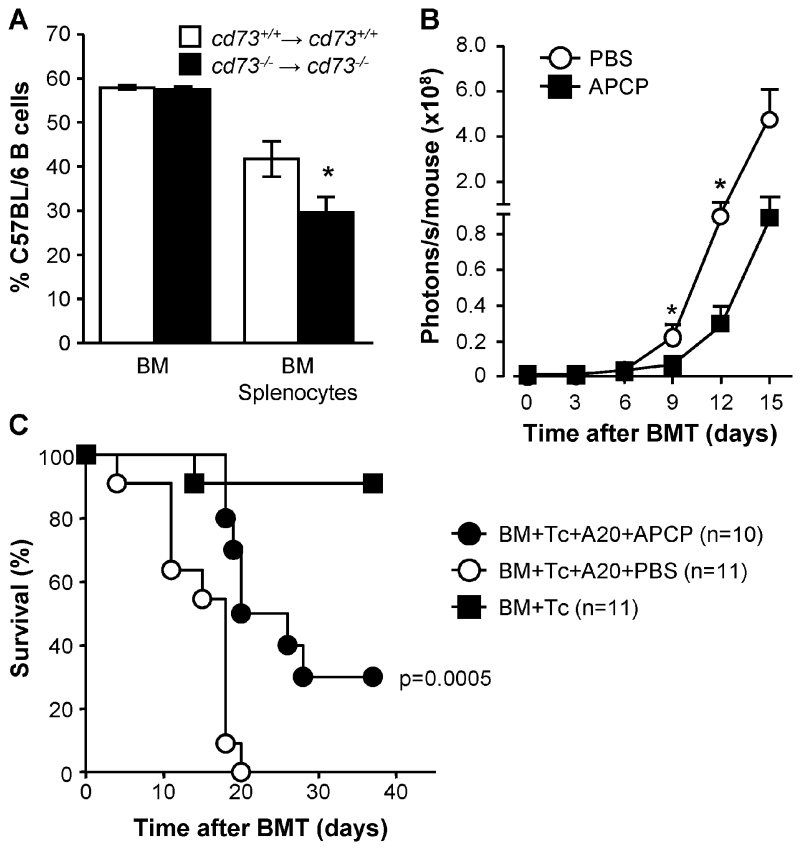

Fig. 5. Cytotoxicity against Host Cells and GVT Activity of Donor T Cells Are Enhanced When CD73 Is Deficient or Inhibited

(A) Five million $\mathrm{BM}$ cells with or without $15 \times 10^{6}$ splenocytes from $c d 73^{+/+}$or $c d 73^{-/-}$BALB/c mice $\left(\mathrm{H}-2 \mathrm{~K}^{d}\right)$ were transplanted into irradiated $c d 73^{+/+}$or $c d 73^{-/-}$C57BL/6 recipients $\left(\mathrm{H}-2 \mathrm{~K}^{b}\right)$, respectively. Six to seven days later, equal numbers of CFSE-labeled B cells from $c d 73^{-/-}$ C57BL $/ 6$ and $c d 73^{-1-}$ BALB/c mice were transferred intravenously into the recipients as targets. Three hours later, recipient spleens were harvested and the CFSE-labeled cells were analyzed for the expression of $\mathrm{H}-2 \mathrm{~K}^{b}$ and $\mathrm{H}-2 \mathrm{~K}^{d}$ by flow cytometry. A decrease in the percentage of $\mathrm{CFSE}^{+} \mathrm{H}-2 \mathrm{~K}^{b}$ target cells is indicative of antihost cytotoxic activity (mean \pm S.D., $n=3$ to $4,{ }^{*} p<$ $0.05)$. (B) Lethally irradiated $\mathrm{BALB} / \mathrm{c}$ mice received $5 \times 10^{6} \mathrm{C} 57 \mathrm{BL} / 6 \mathrm{BM}$ cells and $5 \times 10^{4} l u c^{+} \mathrm{A} 20$ cells on day 0 and $3 \times 10^{5} \mathrm{C} 57 \mathrm{BL} / 6 \mathrm{CD} 4+/ \mathrm{CD} 8^{+}$ splenic $\mathrm{T}$ cells on day 2 . One group $(n=6)$ was intraperitoneally treated with the CD73 inhibitor APCP $(50 \mathrm{mg} / \mathrm{kg} / \mathrm{d})$. On days 0 to 10 after BMT, the other group $(n=6)$ received an equal volume of PBS as vehicle. Expansion of $l u c^{+} \mathrm{A} 20$ tumor cells was measured as photons over the total body area via bioluminescence imaging (mean \pm S.E.M.; day $9,{ }^{*} p=0.0212$; day $12,{ }^{*} p=$ 0.0288 ; day $15, p=0.0509, n=4)$. (C) As in (B), except that the recipient mice received wild-type A20 tumor cells and only $10^{5} \mathrm{CD} 4^{+} / \mathrm{CD} 8^{+}$splenic $\mathrm{T}$ cells. A control group of mice did not receive A20 tumor cells. Survival was monitored for $5 \mathrm{w}$ ( $n=10$ to $11, p=0.0005$ for PBS $v s$. APCP treatment) ${ }^{16)}$

hicle 投与群に比べて APCP 投与群では腫瘍の増殖 が有意に抑制され，腫瘍再発による死亡率も大幅に 改善することができた [Figs. 5(B) and (C)]。こ のように, CD73 の細胞外アデノシン産生能を薬学 的に制御することによって，GVT を効果的に誘導 し，移植後残存腫瘍による再発リスクを軽減し得る 新規な治療法を見い出すことに成功した。

\section{8. おわりに}

われわれは GVHD における細胞外アデノシン産 生系の生理的役割を解明するとともに，細胞外アデ ノシンの産生量や活性制御を行うことで効果的な GVT を誘導する新規治療法の可能性を見い出し
た. ${ }^{16,20)}$ 造血幹細胞移植は，公的細胞バンクの設立 や移植レジメンの改良が進み, 悪性造血器腫瘍の残 された有効な治療法として今後ますます期待され る. 本研究の成果が, 同種造血幹細胞移植に伴う GVHD の発症予防，そしてょり効果的な悪性造血 器腫瘍に対する移植医療を達成するための一助にな れば幸いである。

\section{謝辞本研究に際して, 終始温かな御指導を賜} りました Linda F Thompson 博士（Oklahoma Medical Research Foundation, USA) に心より感謝 申し上げます。また，本総説の一部は Robert Zeiser 博士と Marco Idzko 博士（Freiburg University Medical Center, Germany) との共同研究の成果で あり，両博士の御支援に心より感謝致します。日本 薬学会東北支部奨励賞を受賞する機会を与えて頂き ました東北大学大学院薬学研究科がん化学療法薬学 分野教授 富岡佳久先生に心より感謝致します。

\section{REFERENCES}

1) Welniak L. A., Blazar B. R., Murphy W. J., Annu. Rev. Immunol., 25, 139-170 (2007).

2) Shlomchik W. D., Nat. Rev. Immunol., 7, 340-352 (2007).

3) Chen J. F., Eltzschig H. K., Fredholm B. B., Nat. Rev. Drug Discov., 12, 265-286 (2013) .

4) Junger W. G., Nat. Rev. Immunol., 11, 201212 (2011).

5) Idzko M., Ferrari D., Eltzschig H. K., Nature, 509, 310-317 (2014).

6) Resta R., Yamashita Y., Thompson L. F., Immunol. Rev., 161, 95-109 (1998).

7) Thompson L. F., Eltzschig H. K., Ibla J. C., Van De Wiele C. J., Resta R., Morote-Garcia J. C., Colgan S. P., J. Exp. Med., 200, 13951405 (2004).

8) Mills J. H., Thompson L. F., Mueller C., Waickman A. T., Jalkanen S., Niemela J., Airas L., Bynoe M. S., Proc. Natl. Acad. Sci. USA, 105, 9325-9330 (2008) .

9) Takedachi M., Qu D., Ebisuno Y., Oohara H., Joachims M. L., McGee S. T., Maeda E., McEver R. P., Tanaka T., Miyasaka M., Murakami S., Krahn T., Blackburn M. R., Thompson L. F., J. Immunol., 180, 62886296 (2008). 
10) Eckle T., Krahn T., Grenz A., Kohler D., Mittelbronn M., Ledent C., Jacobson M. A., Osswald H., Thompson L. F., Unertl K., Eltzschig H. K., Circulation, 115, 1581-1590 (2007).

11) Eltzschig H. K., Thompson L. F., Karhausen J., Cotta R. J., Ibla J. C., Robson S. C., Colgan S. P., Blood, 104, 3986-3992 (2004).

12) Eckle T., Faigle M., Grenz A., Laucher S., Thompson L. F., Eltzschig H. K., Blood, 111, 2024-2035 (2008).

13) Deaglio S., Dwyer K. M., Gao W., Friedman D., Usheva A., Erat A., Chen J. F., Enjyoji K., Linden J., Oukka M., Kuchroo V. K., Strom T. B., Robson S. C., J. Exp. Med., 204, 1257-1265 (2007).

14) Sattler C., Steinsdoerfer M., Offers M., Fischer E., Schierl R., Heseler K., Daubener W., Seissler J., Cell Transplant., 20, 12211230 (2011).

15) Wilhelm K., Ganesan J., Muller T., Durr C., Grimm M., Beilhack A., Krempl C. D.,
Sorichter S., Gerlach U. V., Juttner E., Zerweck A., Gartner F., Pellegatti P., Di Virgilio F., Ferrari D., Kambham N., Fisch P., Finke J., Idzko M., Zeiser R., Nat. Med., 16, 14341438 (2010).

16) Tsukamoto H., Chernogorova P., Ayata K., Gerlach U. V., Rughani A., Ritchey J. W., Ganesan J., Follo M., Zeiser R., Thompson L. F., Idzko M., Blood, 119, 4554-4564 (2012) .

17) Wang L., Fan J., Thompson L. F., Zhang Y., Shin T., Curiel T. J., Zhang B., J. Clin. Invest., 121, 2371-2382 (2011).

18) Lappas C. M., Liu P. C., Linden J., Kang E. M., Malech H. L., J. Leukoc. Biol., 87, 345354 (2010).

19) Sevigny C. P., Li L., Awad A. S., Huang L., McDuffie M., Linden J., Lobo P. I., Okusa M. D., J. Immunol., 178, 4240-4249 (2007).

20) Thompson L. F., Tsukamoto H., Chernogorova P., Zeiser R., Oncoimmunology, 2, e22107 (2013). 